\title{
APPLICATION OF LINEAR METHOD OF EVALUATION IN HOLSTEIN-FRIESIAN COWS
}

\author{
Bone Palaševski $^{1}$, Ana Palaševska ${ }^{1}$, Gjoko Bunevski ${ }^{2}$, Nikola Pacinovski ${ }^{1}$, Elena Eftimova ${ }^{1}$ \\ ${ }^{1}$ Institute of Animal Science, "Ss. Cyril and Methodius" University in Skopje, \\ Blvd. Ilinden 92a, Skopje, Republic of Macedonia \\ ${ }^{2}$ Faculty of Agricultural Sciences and Food, "Ss. Cyril and Methodius" University in Skopje, \\ Str. "16-ta Makedonska brigada" no. 3, 1000 Skopje, Republic of Macedonia \\ palasevskib@yahoo.com
}

\begin{abstract}
A b s t r a c t: The evaluation of a type's conformation is a preliminary indicator of lactation, longevity and reproductive performance. Linear assessment belongs to the group of selection measures and consists the basis for evaluation and selection of genetically high-quality breeding heads. The cows should preferably be evaluated during the first lactation, 30 to 150 days after calving. The main objective of our research was a visual assessment of HolsteinFriesian dairy cows, 352 heads in total, on two major farms in the Republic of Macedonia, using a linear evaluation method. The cows in Farm 1 were kept in a loose system of rearing, while the cows in Farm 2 were kept in a tied system of rearing. The following linear features were evaluated: format, chest width, body depth, dairy character, rump position, rump width, rear legs - back view, rear legs - side view, foot angle, fore udder attachment, front teats' positioning, teats' length, udder depth, rear udder height, suspensory ligament, rear teats' positioning and overall condition evaluation, which were then reduced to 4 aggregate features. The analysis of the data obtained, yielded the following average values of those aggregate linear features for Farm 1: format 5.79, dairy character 5.84, legs and dewclaws 5.83, udder 5.76; and for Farm 2: format 5.14, dairy character 5.42, legs and dewclaws 5.38, udder 5.36. Thereby we can draw the conclusion that the values of the aggregate linear features are within the average, being insignificantly higher in Farm 1 with the loose system of rearing. The average milk quantity in the period of 305 days was $7,374 \mathrm{~kg}$ per cow in Farm 1 and $6,895 \mathrm{~kg}$ in Farm 2.
\end{abstract}

Key words: milk cows; body conformation; linear evaluation

\section{ПРИМЕНА НА ЛИНЕАРЕН МЕТОД НА ОЦЕНУВАЊЕ КАЈ ХОЛШТАЈН-ФРИЗИСКИ КРАВИ}

А п с т р а к т: Евалуацијата на конформацијата на типот е прелиминарен показател за млечност, долговечност и репродуктивност. Линеарното оценување спаѓ во групата селекциски мерки и претставува основа за оценување и одбирање генетски квалитетни приплодни грла. Пожелно е кравите да се оценуваат во првата лактација, и тоа од 30-тиот до 150 -тиот ден од телењето. Главна цел на истражувањето претставуваше визуелната процена на холштајн-фризиски крави на две поголеми фарми во Република Македонија, притоа користејќ линеарен метод на евалуација. Кравите во фармата 1 се одгледувани во штали со слободен начин на држење, додека кравите од фармата 2 се одгледувани во штали со врзан систем на одгледување. Се оценуваа следните линеарни особини: формат, ширина на градите, длабина на телото, млечен изглед, агол на сапите, ширина на седните џумки, заден изглед на задните нозе, страничен изглед на задните нозе, аголот на папците, потпора на предниот дел од вимето, поставеност на предните цицки, должина на цицките, длабина на вимето, потпора на задно виме, централен лигамент, поставеност на задните цицки и оцена на кондицијата, кои се сведени на 4 збирни особини. Врз основа на анализата на 352 млечни крави, при земените и оценети линеарни особини, може да се констатира дека се добиени просечни вредности за фармата 1, и тоа: за формат 5,79, млечен карактер 5,84, нозе и папци 5,83 и за виме 5,76, додека пак за фармата 2 се добиени следните вредности: формат 5,14 , млечен карактер 5,42, нозе и папци 5,38 и за виме 5,36. Може да се констатира дека збирните линеарни оцени се во рамките на просечните вредности и незначително повисоки на фармата 1 при слободниот начин на држење на кравите. Според добиените резултати просечното производство на млеко за 305 дена во фармата 1 изнесуваше $7374 \mathrm{~kg}$, додека во фармата 2 изнесуваше $6895 \mathrm{~kg}$.

Клучни зборови: млечни крави; конфирмација на телото; линеарно оценување 


\section{INTRODUCTION}

Linear evaluation belongs to the group of selection measures and is the basis for evaluation and selection of quality breeding heads. The selection according to the external features in a great deal contributes to the improvement of certain productive and reproductive properties. For this reason, the linear evaluation of the production type and the individual exterior measures in the controlled animals ought to be performed according to the international standards, by the races, i.e. the production types of cattle. The number of external features examined, the way of animals' behaviour, the scales used in the linear evaluation and the obtained data processing are described in detail by the approved breeding programme for the particular cattle races according to the ICAR recommendations.

The breeding programme for Holstein-Friesian race of cattle in $\mathrm{R}$. Macedonia defines the breeding goals, the size of the population in which the programme is carried out, the breeding methods, the selection programme and the programme for a gene bank, the developmental and research activities for increasing the programme's efficiency, the factors for better breeding of cattle, the providing for genetic improvement, as well as improvement of the quality of the animal products obtained from cattle. The breeding programme for Holstein-Friesian cattle in R. Macedonia includes more than 30 features, divided in a few groups: productive, reproductive, external and linear features.

The linear features are evaluated according to the international standards on Holstein-Friesian race, namely: 17 features for cows bred in a tied system, and 18 features for cows bred in a loose system. It is preferable the cows to be evaluated during the first lactation - namely in the period from the $30^{\text {th }}$
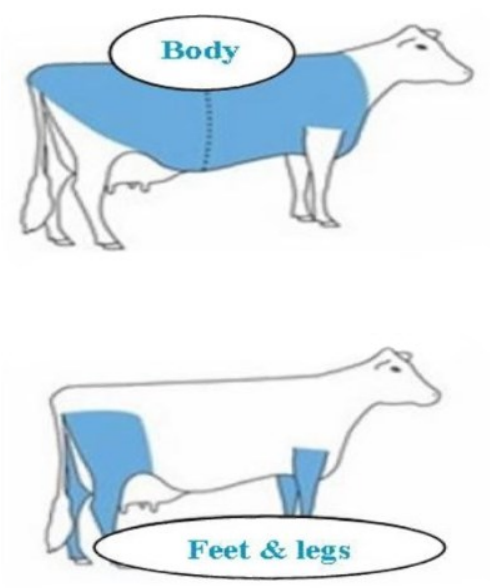

to the $150^{\text {th }}$ day after calving, because of the udder's activity and capacity as well as because of the presumption that the genetic basis is more reliable for evaluation in this period since the influence of external factors is smaller (Pantelić et al., 2007a).

In the evaluation a scale from 1 to 9 is used, where the mark 9 denotes ideally expressed feature, the mark 5 denotes averagely expressed feature, and the mark 1 denotes the most poorly expressed feature. However, either the marks are high or low, it doesn't necessarily mean that the animals are less worthy (Pogačar et al., 1995).

\section{MATERIAL AND METHODS}

The main objective of this research was a visual assessment of cows from Holstein-Friesian (black and white) race in two major farms in R. Macedonia, by using a linear evaluation method. The cows in Farm 1 were kept in cowsheds with loose system of rearing, while the cows in Farm 2 were kept in cowsheds with tied system of rearing. According to the recommendations by the World Association for Holstein-Friesian Cattle, the following linear features were evaluated, all of them later being reduced to 4 aggregate features (Figure 1):

- Format. The evaluation is performed using a linear scale of marks 1-9; the mark 1 means height of the rump of $130 \mathrm{~cm}$, the mark 5 means height of $142 \mathrm{~cm}$, and 9 means height of the rump of 145 $\mathrm{cm}$.

- Chest width. It is measured as the vertical distance between the front legs at the level of the lower plain of the chest; the marks 1-3 mean narrow chest, 4-6 medium wide chest, and 7-9 wide chest).
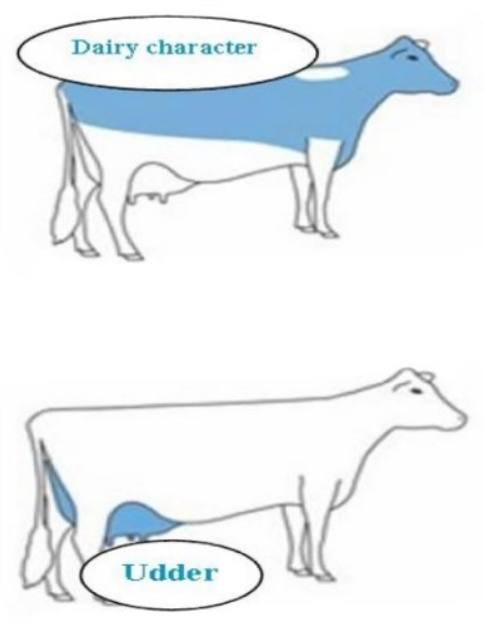

Fig. 1. Aggregate features at the linear evaluation of the cows from the black and white population 
- Body depth. It is measured from the top point of the back down to the bottom of the belly at the rearmost rib as the deepest point; the marks 1-3 mean shallow, 4-6 medium deep, and 7-9 deep body.

- Dairy character. This feature is defined by the angularity of the body and the position of the ribs; the marks 1-3 mean poor angularity, 4-6 medium angularity, and 7-9 good angularity of the body.

- Rump position. It is measured from the hips and the pin bones; the marks 1-3 mean poor seat width, 4-6 medium width, and 7-9 large seat width.

- Rump width. It is the distance between the pin bones, viewed from the back side of the cow; the marks 1-3 mean narrow distance, 4-6 medium distance, and 7-9 wide distance.

- Back view of the rear legs. Here the positioning of the rear legs viewed from behind is evaluated; the mark 1 means legs of an extreme X-shape, the mark 5 means moderately $\mathrm{X}$-shaped legs, and the mark 9 - parallelly positioned legs.

- Side view of the rear legs. Here the angle formed by the hock on the inner side of the legs is measured; the mark 1 means straightened position (around $160^{\circ}$ ), the mark 5 - moderately angled position (around $147^{\circ}$ ), and the mark 9 means angled position (around $134^{\circ}$.

- Dewclaw angle. The angle formed at the front of the hoof of the rear right leg is evaluated; the marks 1-3 mean obtuse angle, 4-6 medium angle, and 7-9 acute angle.

- Fore udder attachment. The quality of the udder front quarters' attachment to the belly wall is evaluated; the marks 1-3 mean weak, loose attachment, 4-6 medium attachment, and 7-9 firm attachment.

- Front teats' positioning. Evaluated is the positioning of the front teats related to the imagined vertical at the left and the right half of the udder, viewed from behind; the marks 1-3 mean front teats positioned outwards, 4-6 vertically positioned, and 7-9 positioned inwards.

- Teats' length. The length of the teats at the front quarters of the udder is evaluated; the marks 1-3 mean short teats, 4-6 medium long, and 7-9 long teats.

- Udder depth. The position of the lowest point of the udder in relation to the hocks is evaluated; the mark 1 means udder below the level of the hocks - deep udder, the mark 5 means udder at the same level with the hocks, and the mark 9 means udder above the level of the hocks - shallowly positioned udder.

- Rear udder height. The distance between the bottom of the vulva and the hock is evaluated; the marks 1-3 mean short distance, 4-6 medium distance, and the marks 7-9 long distance.

- Central ligament. Here the depth of the udder central ligament's cleavage is evaluated; the mark 1 means flat bottom of the rear udder, the mark 4 means poorly defined, and the mark 9 means deeply defined bottom.

- Rear teats' positioning. Evaluated is the positioning of the rear teats in relation to the imagined central vertical at the udder's quarter; the marks 1-3 mean rear teats positioned outwards, the marks 4-6 mean central positioning, and the marks 7-9 mean teats positioned towards the suspensory ligament.

- Overall condition evaluation. The coverage of the pelvis bones and of the vertebra along the line of the back, the size of the milk wells, the pronouncement of the ribs and the curvature of the thighs are evaluated, by the scale from 1 to 9 , where the mark 1 means starved, and the mark 9 means fattened condition.

\section{RESULTS AND DISCUSSION}

According to the recommendations of the World Association for Holstein-Friesian Cattle, 15 to 24 features are evaluated according to the needs, but most often it is recommended 18 linear features to be evaluated in the cows of the black and white population. In our research, 17 linear features of the examined cows were evaluated, with marks from 1 to 9 , and after that all the features were reduced to 4 aggregate features, according to the recommendations of the European Holstein Federation (EHF), ICAR and the World Association for Holstein-Friesian Cattle.

Based on the analyses performed, the following results were obtained:

According to Table 1, the average value for the feature format in the examined cows from Farm 1 was 5.79, with standard deviation of 1.27 and coefficient of variation of 21.98. The individual values ranged from 3 to 8 . The average value for the feature dairy character was 5.84, with standard deviation of 1.61 and coefficient of variation of 27.60. The individual values ranged from 3 to 9 . The average value 
for the feature legs and dewclaws was 5.81, with standard deviation of 1.39 and coefficient of variation of 23.87. The individual values ranged from 3 to 9 . The average value for the feature udder was 5.76, with standard variation of 1.19 and coefficient of variation of 20.60. The individual values ranged from 3 to 9 . The average milk production at Farm 1 in the period of 305 days was $7,374 \mathrm{~kg}$ per head.

\section{Table 1}

\section{Evaluation of aggregate linear features in the black-white cows from Farm 1}

\begin{tabular}{|lcccc|}
\hline Parameter & Body & Dairy character & Feet and legs & Udder \\
\hline$\overline{\mathrm{x}}$ & 5.79 & 5.84 & 5.83 & 5.76 \\
\hline $\mathrm{SD}$ & 1.27 & 1.61 & 1.39 & 1.19 \\
\hline $\mathrm{CV}$ & 21.98 & 27.60 & 23.87 & 20.60 \\
\hline $\min$ & 3 & 3 & 3 & 3 \\
\hline $\max$ & 8 & 9 & 9 & 9 \\
\hline
\end{tabular}

According to Table 2, the average value for the feature format in the examined cows from Farm 2 was 5.14, with standard deviation of 1.07 and coefficient of variation of 20.76 . The individual values ranged from 3 to 8 . The average value for the feature dairy character was 5.42, with standard deviation of 1.35 and coefficient of variation of 24.84. The individual values ranged from 3 to 9 . The average value for the feature legs and dewclaws was 5.38, with standard deviation of 1.17 and coefficient of variation of 21.67. The individual values ranged from 3 to 8 . The average value for the feature udder was 5.35 , with standard variation of 1.13 and coefficient of variation of 21.05 . The individual values ranged from 3 to 9. The average milk production at Farm 2 in the period of 305 days was $6,895 \mathrm{~kg}$ per head.

\section{Table 2}

Evaluation of aggregate linear features in the black-white cows from Farm 2

\begin{tabular}{|lcc|cc|}
\hline Parameter & Body & Dairy character & Feet and legs & Udder \\
\hline$\overline{\mathrm{x}}$ & 5.14 & 5.42 & 5.38 & 5.36 \\
\hline $\mathrm{SD}$ & 1.07 & 1.35 & 1.17 & 1.13 \\
\hline $\mathrm{CV}$ & 20.76 & 24.84 & 21.67 & 21.05 \\
\hline $\min$ & 3 & 3 & 3 & 3 \\
\hline $\max$ & 8 & 9 & 8 & 9 \\
\hline
\end{tabular}

Based on the analysis of the evaluated linear features at Farm 1 and Farm 2, we can draw the conclusion that the parameters measured in the cows are satisfactory and within the limits of the average values. Insignificantly higher values were obtained in Farm 1, where the cows were kept using the loose system of rearing.

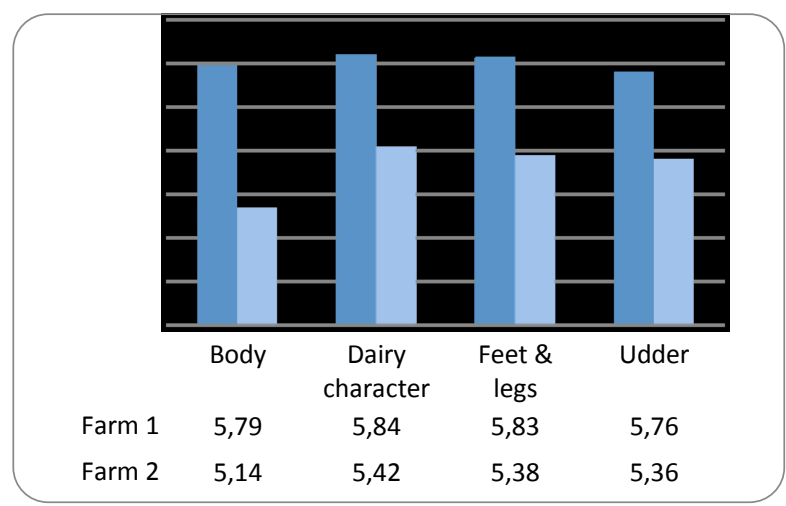

Chart 1. Average marks for aggregate linear features in Farm 1 and Farm 2

\section{CONCLUSION}

The evaluation of the type's conformation is a preliminary indicator of lactation, longevity and reproductivity. The main goal of the evaluation was to select those cows of the same race which can give the biggest yield with a minimum of costs.

The analysis of the evaluated linear features gave the following values for Farm 1: format 5.79, dairy character 5.84, legs and dewclaws 5.83 , and udder 5.76, which are insignificantly higher than those obtained in Farm 2: format 5.14, dairy character 5.42, legs and dewclaws 5.38 and udder 5.36.

The results obtained from the performed examinations and evaluations are a good basis for conducting appropriately designed selection in the controlled farms.

\section{REFERENCES}

Bunevski, Gj., Trajkovski, T.: Application of the linear model for conformation judgement of black and white cows type. Symposium of Livestock Production, 2001.

Pantelič, V., Aleksić, S., Ostojić-Andrič, D., Sretenović, Lj., Petrović, M. M., Novaković, Ž.: Linear evaluation of the type of Holstein-Frisian bull dams. Archiva Zootechnica 13, 1, 83-90.(2010).

Pantelić, V., Skalicki, Z., Petrović, M. M., Latinović, D., Aleksić, S., Miščević, B., Ostojić, D.: Telesna razvijenost bikovskih majki simentalske rase. Biotehnologija u stočarstvu, 22 (3-4), pp. 23-32 (2006). 
Pantelić, V., Skalicki, Z., Petrovći, M. M., Latinović, D., Aleksič, S., Miščević, B., Ostojić, D.: Linearno ocenivanje bikovski majki simentalske rase. Savremena poljoprivreda 1-2, pp. 49-54 (2007a).

Pantelić, V., Skalicki, Z., Petrović, M. M., Latinović, D., Aleksić S., Miščević, B., Ostojić, D.: Variability of linearly evaluated traits of type of simental bulldams. Biotehnologija u stočarstvu, 23 (5-6), pp. 201-208 (2007b).
Pogačar, J., Kunstelj, P., Zupančić, A., Čeh, J.: Linearno opisovanje in ocenjevanje krav. Domžale, Govedorejska služba Slovenije, Biotehniška fakulteta, Oddelek za zootehniko: 21 str., 1995.

Кучевић, Д.: Технологија говедарске йроизводње. Практикум, 2015. 
